\title{
Intraoperative diagnosis of malignant brain gliomas using terahertz pulsed spectroscopy and optical coherence tomography
}

\author{
K.I. Zaytsev ${ }^{1,2, *}$, I.N. Dolganova ${ }^{2,3}$, N.V. Chernomyrdin ${ }^{1,2}$, \\ G.A. Komandin ${ }^{1}$, M.A. Schcedrina ${ }^{4}$, S.-I.T. Beshplav ${ }^{5}$, S.A. Goryaynov ${ }^{5}$, \\ V.E. Karasik ${ }^{2}$, I.V. Reshetov ${ }^{4}$, A.A. Potapov ${ }^{5}$, and V.V. Tuchin ${ }^{6,7,8}$ \\ ${ }^{1}$ Prokhorov General Physics Institute of the Russian Academy of Sciences, Moscow 119991, Russia; \\ ${ }^{2}$ Bauman Moscow State Technical University, Moscow 105005, Russia; \\ ${ }^{3}$ Institute of Solid State Physics of the Russian Academy of Sciences, Chernogolovka 142432, Russia; \\ ${ }^{4}$ Sechenov University, Moscow 119991, Russia; \\ ${ }^{5}$ Burdenko Neurosurgery Institute, Moscow 125047, Russia; \\ ${ }^{6}$ Saratov State University, Saratov 410012, Russia, Russia; \\ ${ }^{7}$ Tomsk State University, Tomsk, 634050; \\ ${ }^{8}$ Institute of Precision Mechanics and Control of the Russian Academy of Sciences, Saratov 410012, Russia \\ *E-mail: kirzay@gmail.com
}

An intraoperative diagnosis of malignant brain gliomas remains a challenging problem of modern neurosurgery [1]. A complete resection of glioma is the most important factor, determining an efficiency of its treatment [2]; while an incomplete resection, caused by inaccurate detection of the tumor margins, increases a probability of its recurrence. The existing methods of the intraoperative neurodiagnosis of tumors are plagued with limited sensitivity and specificity, some of them remains laborious, time-consuming and/or rather expensive. Therefore, development of novel methods for the intraoperative diagnosis of gliomas relying on modern instruments of medical spectroscopy and imaging is a topical problem of medicine, physics, and engineering [3,4].

In our research, we studied a potential of terahertz (THz) pulsed spectroscopy (TPS) [5-9] and optical coherence tomography (OCT) [10-12] in the intraoperative diagnosis of brain tumors, with a strong emphasize on brain gliomas.

First, we performed in vitro $\mathrm{THz}$ spectroscopy of human brain gliomas of different grade. In order to fix tissues for the $\mathrm{THz}$ measurements, we applied the gelatin embedding, which allows to preserve tissues from hydration/dehydration; thus, sustaining the $\mathrm{THz}$ dielectric response of tissues unaltered for a long time after the surgery. We applied the laboratory TPS setup to study in vitro the refractive index and the amplitude absorption coefficient of intact tissues and gliomas. We observed significant differences between the $\mathrm{THz}$ characteristics of normal and pathological tissues of the brain [13]. This highlights a potential of $\mathrm{THz}$ technology in the label-free intraoperative diagnosis of brain tumors. Particularly, THz imaging and microscopy [14] can be applied for the intraoperative detection of the tumor margins in order to ensure its gross-total resection. Furthermore, the single-point $\mathrm{THz}$ spectroscopy and reflectometry could be integrated into modern neuroprobes, which are based on sapphire shaped crystals and yields combining the $\mathrm{THz}$ waveguiding $[16,17]$ with diagnosis, aspiration and laser coagulation of brain tissues [18-20].

Second, we studied intact tissues and gliomas of the brain using OCT. For each tissue class, we analyzed a slope of the OCT signal in a depth. This slope reveals statistical difference between healthy and pathological tissues of the brain [10], which could be further emphasized using modern wavelet-domain denoising of OCT data [12]. Thus, the results of our study showcase a potential of OCT in intraoperative neurodiagnosis of brain gliomas.

Thereby, this work yields preliminary analysis (feasibility test), which aims to objectively uncover strengths and weaknesses of TPS and OCT from the viewpoint of their use in intraoperative diagnosis of human brain tumors before committing to a fullblown study involving measurements and analysis of a large amount of tissue sample, both ex vivo and in vivo.

This work was supported by the Russian Foundation for Basic Research (RFBR), Projects \# 18-3800504 and 18-38-00853.

\section{References}

1. Ostrom, Q.T., Gittleman, H., Xu, J., Kromer, C., Wolinsky, Y., Kruchko, C., Barnholtz-Sloan, J.S., CBTRUS Statistical Report: Primary Brain and Other Central Nervous System Tumors Diagnosed in the United States in 20092013 // Neuro-Oncology, 2016, V.18, No.5, P.1-75.

2. Phuphanich, S., Ferrall, S., Greenberg, H., Longterm survival in malignant glioma. Prognostic factors // The Journal of the Florida Medical Association, 1993, V.80, P. 181-184.

3. Pustogarov, N., Panteleev, D., Goryaynov, S.A., Ryabova, A.V., Rybalkina, E.Y., Revishchin, A., Potapov, A.A., Pavlova, G., Hiding in the Shadows: CPOX Expression and 5-ALA Induced Fluorescence in Human Glioma Cells // Molecular Neurobiology, 2017, V.54., No.7, P.5699-5708.

4. Potapov, A.A., Goryaynov, S.A., Okhlopkov, V.A., Shishkina, L.V., Loschenov, V.B., Savelieva, T.A., Golbin, D.A., Chumakova, A.P., Goldberg, M.F., Spallone, A., Varyukhina, M.D., Laser biospectroscopy and 5-ALA fluorescence navigation as a helpful tool in the meningioma resection // Neurosurgical Review, 2016, V.39, No.3, P.437-447.

5. Zaytsev, K.I., Kudrin, K.G., Karasik, V.E, Reshetov, I.V., Yurchenko, S.O., In vivo terahertz spectroscopy of pigmentary skin nevi: Pilot study of non-invasive early diagnosis of dysplasia // Applied Physics Letters, 2015, V. 106, P. 053702. 
6. Zaytsev, K.I., Gavdush, A.A., Chernomyrdin, N.V., Yurchenko, S.O., Highly Accurate in Vivo Terahertz Spectroscopy of Healthy Skin: Variation of Refractive Index and Absorption Coefficient Along the Human Body // IEEE Transactions on Terahertz science and Technology, 2015, V. 5, No.5, P. 817-827.

7. Zaytsev, K.I., Chernomyrdin, N.V., Kudrin, K.G., Reshetov, I.V., Yurchenko, S.O., Terahertz spectroscopy of pigmentary skin nevi in vivo // Optics and Spectroscopy, 2015, V. 119, No.3, P. 404-410.

8. Reshetov, I., Zaytsev, K., Kudrin, K., Karasik, V., Yurchenko, S., Shcherbina, V., Terahertz spectroscopy: Pilot study of non-invasive early diagnosis of dysplasia and melanoma // European Journal of cancer, 2015, V.51, No.3, P. S167.

9. Zaytsev K.I., Katyba G.M., Kurlov V.N., Shikunova I.A., Karasik V.E., Yurchenko S.O., Terahertz Photonic Crystal Waveguides Based on Sapphire Shaped Crystals // IEEE Transactions on Terahertz science and Technology, 2016. V.6, No. 4, P. 576-582.

10. Dolganova, I.N. Aleksandrova, P.V., Beshplav, S.I.T, Chernomyrdin, N.V., Dubyanskaya, E.N., Goryaynov, S.A., Kurlov, V.N., Reshetov, I.V., Potapov, A.A., Tuchin, V.V. Zaytsev, K.I., Wavelet-domain de-noising of OCT images of human brain malignant glioma // Proceedings of SPIE, 2018, V. 10717, P. 107171X

11. Carrasco-Zevallos, O.M., Viehland, C., Keller, B., Draelos, M., Kuo, A.N., Toth, C.A. and Izatt, J.A., Review of intraoperative optical coherence tomography: technology and applications // Biomedical Optics Express, 2018, V.8, No.3., P.1607-1637.

12. Dolganova, I.N., Chernomyrdin, N.V., Aleksandrova, P.V., Beshplav, S.-I.T, Potapov, A.A., Reshetov, I.V., Kurlov, V.N., ., Tuchin, V.V. Zaytsev, K.I., Nanoparticleenabled experimentally trained wavelet-domain denoising method for optical coherence tomography // Journal of Biomedical Optics, 2018, V.23, No.9, P.091406.

13. Chernomyrdin, V.N., Gavdush; A.A., Beshplav, S. I.T.,Malakhov, K.M., Kucheryavenko, A.S., Katyba, G.M., Dolganova, I.N., Goryaynov, S.A., Karasik, V.E., Spektor, I.E., Kurlov, V.N., Yurchenko,S.O., Komandin,G.A., Potapov,A.A., Tuchin,V.V., Zaytsev,K.I., In vitro terahertz spec- troscopy of gelatin-embedded human brain tumors: a pilot study // Proceedings of SPIE, 2018, V. 10716, P. 107160S.

14. Chernomyrdin, N.V. Kucheryavenko, A.S. Kolontaeva, G.S., Katyba, G.M., Dolganova, I.N., Karalkin, P.A., Ponomarev, D.S., Kurlov, V.N., Reshetov, I.V., Skorobogatiy, M. , Tuchin, V.V., Zaytsev, K.I., Reflection-mode continuous-wave $0.15 \lambda$-resolution terahertz solid immersion microscopy of soft biological tissues // Applied Physics Letters, 2018, V.113, No. 11, P. 111102 ,

15. Katyba, G.M., Zaytsev, K.I., Dolganova, I.N., Shikunova, I.A., Chernomyrdin, N.V., Yurchenko, S.O., Komandin, G.A., Reshotov, I.V., Nesvizhevsky, V.V. and Kurlov, V.N., Sapphire shaped crystal for waveguiding, sensing and exposure applications // Progress in Crystal Growth and Characterization of Materials (accepted, 2018).

16. Zaytsev K.I., Katyba G.M., Kurlov V.N., Shikunova I.A., Karasik V.E., Yurchenko S.O., Terahertz photonic crystal waveguides based on sapphire shaped crystals // IEEE Transactions on Terahertz science and Technology, 2016, V.6, No. 4, P. 576-582.

17. Katyba G.M., Zaytsev K.I., Chernomyrdin N.V. Shikunova I.A., Komandin G.A., Anzin V.B., Lebedev S.P., Spektor I.E., Karasik V.E., Yurchenko S.O., Reshetov I.V., Skorobogatiy M., Kurlov V.N. and Skorobogatiy M., Sapphire photonic crystal waveguide for terahertz sensing in aggressive environments // Advanced Optics Materials, 2018, DOI: 10.1002/adom.201800573.

18. Shikunova I.A., Stryukov D.O., Rossolenko S.N., Kiselev A.M., Kurlov V.N., Neurosurgery contact handheld probe based on sapphire shapedcrystal // Journal of Crystal Growth, 2017, V. 457, PP. 265-269.

19. Shikunova I.A., Zaytsev K.I., Stryukov D.O., Dubyanskaya E.N., Kurlov V.N., Neurosurgical sapphire handheld probe forintraoperative optical diagnostics, laser coagulationand aspiration of malignant brain tissue // Proceedings of SPIE, 2017, V. 10411, P. 104110Q

20. Katyba G.M., Zaytsev K.I., Dolganova I.N., Shikunova I.A., Chernomyrdin N.V., Yurchenko S.O., Komandin G.A., Reshetov I.V., Nesvizhevsky V.V., Kurlov V.N., Sapphire shaped crystals for waveguiding, sensing and exposure applications // Progress in Crystal Growth and Characterization of Materials, 2018, accepted. 